\title{
Stratigraphic correlation of the Danish onshore and offshore Tertiary successions based on sequence stratigraphy
}

\author{
OLAF MICHELSEN
}

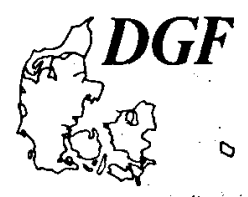

\author{
Michelsen, O.: Stratigraphic correlation of the Danish onshore and offshore Tertiary successions \\ based on sequence stratigraphy. Bulletin of the Geological Society of Denmark, Vol. 41, pp. \\ 145-161. Copenhagen, 1994-11-30. \\ https://doi.org/10.37570/bgsd-1995-41-14
}

\begin{abstract}
The results of a sequence stratigraphic study of the Tertiary sedimentary succession in the Danish North Sea sector, and the adjacent parts of the Norwegian, German, and Dutch sectors are reviewed in the present paper. Lithology and thickness variations of seven major sequence stratigraphic units, comprising twentyone sequences, are shortly described.

The chronostratigraphic and genetic relationships between the North Sea sequences and the Danish onshore lithostratigraphic formations are emphasized. Six major sequence stratigraphic boundaries are pointed out, being time-equivalent with regional unconformities in the onshore area.

The six surfaces bound five sedimentary packages, which are isochronous in their recognized lateral extension, and comprise genetically related deposits. It is suggested to define the five units as allostratigraphic units, and thus to create a stratigraphic subdivision, which is mappable in the southeastern North Sea region, possibly in the main part of the North Sea. The five allostratigraphic units can be identified in all areas by the available data; seismic sections and logs in the offshore area, and lithology in onshore outcrops and shallow wells.

The definition of an allostratigraphic scheme would create a common nomenclature across the national borders and the present coastlines, and hopefully increase the accuracy of the chro-nostratigraphic correlation between profiles in the North Sea region.
\end{abstract}

Olaf Michelsen, Department of Earth Sciences, Aarhus University, DK-8000 Århus, Denmark. 16th December 1993.

\section{Introduction}

The present paper reviews the most recent advances in the research of the Tertiary stratigraphy in the Danish North Sea sector (Fig. 1), including a new sequence stratigraphic subdivision of the Cenozoic section. A stratigraphic correlation of the North Sea sequences with the Danish Tertiary section is presented (Fig. 2).

The chronostratigraphic and genetic relationships between the North Sea sequences and the Danish onshore lithostratigraphic formations are emphasized within the frame of sequence stratigraphy.

The six major stratigraphic surfaces are identified in the southeastern North Sea region, including the Danish onshore area. They are associated with regional unconformities. It is suggested to define five units as allostratigraphic units, which are isochronous in their recognized lateral extension, and comprise genetical related deposits.

At present there is established different lithostratigraphic schemes in the Danish onshore area and in each of the North Sea sectors (Fig. 2). A precise lateral extension of the formations is often difficult to identify. The suggested allostratigraphic scheme would incorporate all deposits in the southeastern North Sea region, including well-defined lithostratigraphic units, into a chronostratigraphic framework. It would create a common nomenclature across the national borders and the present coastlines.

The present paper was compiled for presentation at the celebration of the centenary of the Danish Geological Society. It is based primarily on a sequence stratigraphic study of the Cenozoic succession in the southeastern North Sea. This Cenozoic North Sea Study was carried out in the period 1990-1992 by a group of geologists at the Department of Earth Sciences, Aarhus University. The study was an integrated stratigraphic study, comprising analyses of seismic sections, petrophysical logs, well samples, and biostratigraphic studies of foraminifera, dinoflagellates, and calcareous nannofossils. Stratigraphic, palaeogeographic, and palaeoecological information from the Danish onshore area was integrated in the study. The study area comprised the Danish North Sea sector and the adjacent Norwegian, German, and Dutch sectors (Fig. 1). The seismic interpretations was accomplished by Henrik Jordt, the log and sample interpretations by Mette Danielsen, and the biostratigraphic analyses by Claus 


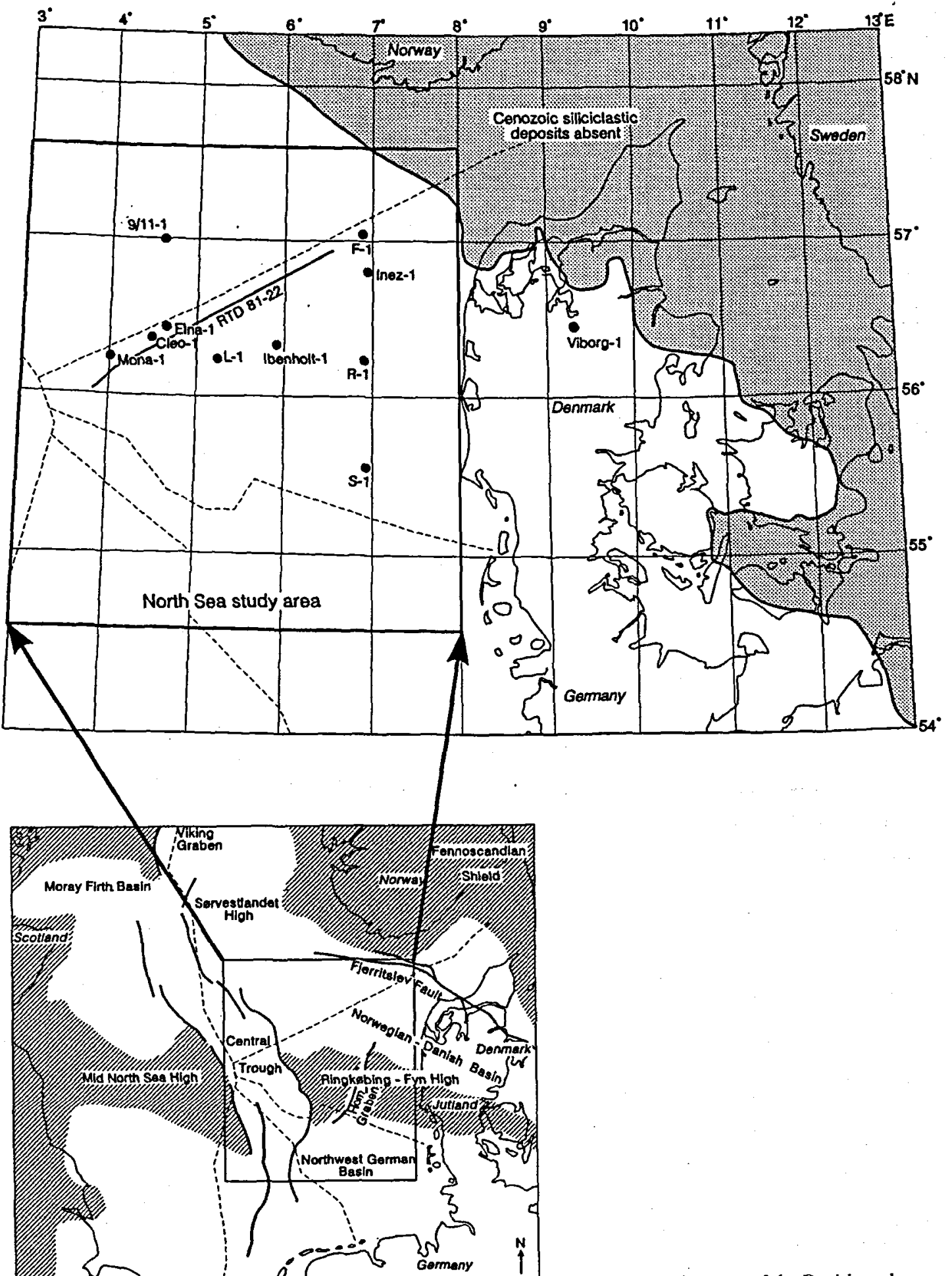

Fig. 1: Location map of the Danish onshore and North sea areas, including the study area of Cenozoic North Sea Study described in Michelsen et al. (in press/a). Locations of seismic sections and wells mentioned in this paper are shown. 


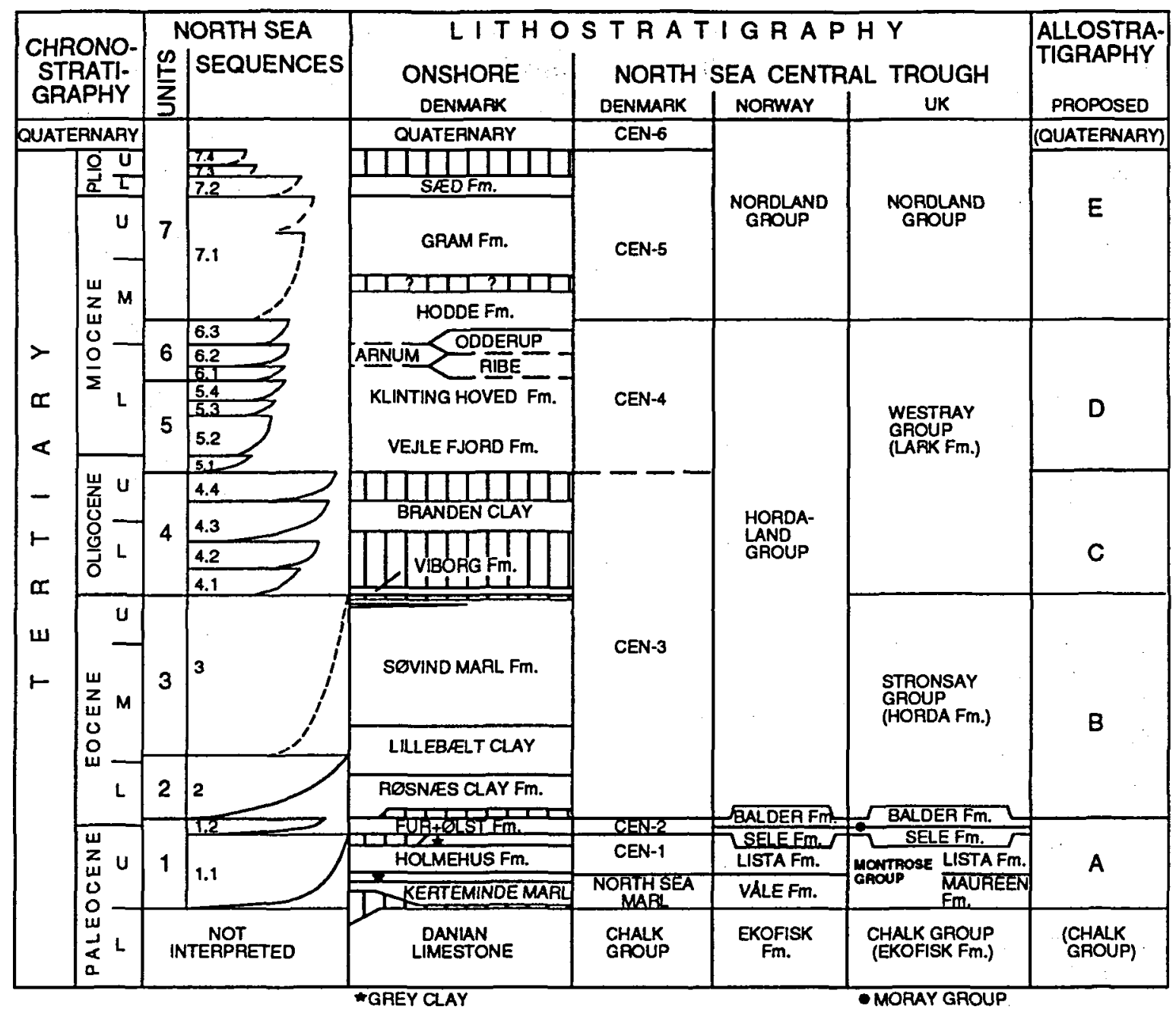

Fig. 2: Stratigraphic scheme including the Danish North Sea Tertiary sequences, the Danish onshore lithostratigraphy, and the lithostratigraphic shemes from the Danish, the Norwegian, and the UK Central Trough. A regional allostratigraphic scheme is proposed. The Danish onshore lithostratigraphic scheme is from Michelsen et al. (in press/a), and compiled by C. Heilmann-Clausen, G. V. Laursen, and E. Thomsen. The offshore schemes are from Kristoffersen \& Bang (1982), Isaksen \& Tonstad (1989), and Knox \& Holloway (1992), respectively.

Heilmann-Clausen, Gitte V. Laursen and Erik Thomsen. The present author supervised the compilation of data and performed the sequence stratigraphic interpretation.

Additional investigations are going on in order to establish a more direct tie between the offshore and onshore data, and to create a further detailed stratigraphic correlation. These studies are carried out by the above-mentioned group of geologists in cooperation with colleagues from the Geological Survey of Denmark.

\section{Regional geology}

During the late Palaeozoic and the Mesozoic, the North Sea region was dominated by two east-west trending basins, the Northern Permian Basin (including the Danish Basin) and the Southern Permian Basin, separated by the Ringkøbing-Fyn High and Mid North Sea High trend. This trend was cut by the north-south oriented Central Trough and the Horn Graben.

During the Cenozoic time, the North Sea region constituted a large epicontinental basin with a north-south axis above the older Central Trough structures (Nielsen et al., 1986). The basin was flanked by the positive areas of Scandinavia to the east and the British Isles to the west. The Cenozoic deposits in the central part of the North Sea Basin reach a thickness of more than $3000 \mathrm{~m}$, representing most of the erathem. Clay and silty clay, deposited in a sublittoral to upper bathyal environment, constitute the major part of the succession in the North Sea. 
The Cenozoic succession in the Danish North Sea sector is largely unfaulted. The local depositional patterns are mainly influenced by 1) inversion tectonism during the Early. Tertiary in the eastern part of the Central Trough, 2) syn-depositional halokinetic movements of the Zechstein evaporites and salt induced faulting, 3) differential compaction, and 4) faulting with a very small displacement within the area of the Central Trough and the westernmost Ringkøbing-Fyn High.

The depositional environments of Cenozoic deposits in the Danish North Sea sector are only poorly documented by cuttings samples and very few conventional cores. The sedimentary facies is primarily known from log interpretations. The lithology of the Paleocene sediments resembles those described by Isaksen \& Tonstad (1989) from the southern part of the Norwegian sector. The lower Eocene comprises reddish and greenish clays, resembling those known from the Danish onshore Røsnæs Clay and Lillebælt Clay Formations (Heilmann-Clausen, 1989), whereas the overlying Eocene sediments may only be characterized as marine clay deposits. The Oligocene and Miocene sediments consist of clay with an upward increasing amount of silt and mica deposited in a sublittoral environment. A few wells in the northeastern part of the Danish sector have penetrated rather thick sand deposits, probably belonging to a marine nearshore environment.

Most of Tertiary strata in the Danish onshore area are marine. Marginal Palaeogene sediments were probably deposited on the Fennoscandian Shield and the Fennoscandian Border Zone, but have been removed as a result of the late Cenozoic uplift and the subsequent erosion (Doré, 1992). Only during a part of the Miocene time, the coastline was situated in Denmark.

The post-Danian Cenozoic deposits onshore Denmark are documented in outcrops and cored shallow boreholes. Mainly clay- and marl-dominated marine sediments known from the Upper Paleocene - Upper Oligocene (Christensen \& Ulleberg, 1973, 1974, Dinesen et al., 1978, Heilmann-Clausen et al., 1985, Heilmann-Clausen, 1989). The known total thickness of the post-Danian Palaeogene section is approx. $350 \mathrm{~m}$. The uppermost Oligocene - Recent deposits are characterized by more coarse-grained sediments, deposited in shallow marine, lagoonal, or floodplain environments (Larsen \& Dinesen, 1959, Rasmussen, 1961, Radwanski et al., 1975, Friis, 1978, Koch, 1989). The Neogene section has a thickness comparable with that of the Palaeogene.

Several regional unconformities separate distinct lithologies in the Danish onshore sections (Buchardt-Larsen \& Heilmann-Clausen, 1988). Some unconformities are major, and associated with erosion, e.g. at the top of the Danian limestone, at the base of the Viborg Formation, and especially at the base of the Vejle Fjord Formation. Other unconformities appear to be largely unaffected by erosion, e.g. at the base of the Ølst Formation and at the base of the Røsnæs Clay Formation.

\section{Previous stratigraphic investigations}

Investigation of the Danish onshore Cenozoic section has a long history, and the stratigraphy is relatively well known as referred to in the section above. The lithostratigraphic subdivision presented in Figure 2 follows Buchardt-Larsen \& Heilmann-Clausen (1988).

The Cenozoic section in the Danish North Sea sector was penetrated for the first time in 1966 by the hydrocarbon exploration well, A-1. A base Tertiary structural map was published by Sorgenfrei (1969), indicating that the Cenozoic has a maximum thickness of more than $3500 \mathrm{~m}$ in the central part of the North Sea.

The post-Danian Cenozoic sedimentary succession of the Danish Central Trough was subdivided into seven informal lithostratigraphic units by Kristoffersen \& Bang (1982). These seven units were defined by $\log$ features, which largely represent the local lithology and sedimentary facies. The units are, therefore, diachronic outside the Central Trough in that part of the Tertiary, dominated by prograding sediment complexes.

Nielsen et al. (1986) mapped the Cenozoic chronostratigraphic units and formally defined lithostratigraphic units in the central and northern North Sea. They identified different rates of subsidence of the various subbasins. The main depocentres of the Paleocene and Eocene deposits were located in the northwestern part of the North Sea, whereas the Oligocene and Miocene depocentres were found in the Norwegian and Danish part of the Central Trough.

The approximate chronostratigraphic age of the lithostratigraphic units established by Kristoffersen \& Bang (1982) are supported by preliminary biostratigraphic data (e.g. Rasmussen, 1974, 1978). A large number of stratigraphic data are compiled in a comprehensive paper, covering large parts of the onshore and offshore North Sea region (Vinken, 1988).

Clausen (1991) mapped a large number of seismic sequences in the northern Danish Central Trough, and suggested a preliminar curve of coastal onlap. Vail et al. $(1977 \mathrm{a}, \mathrm{b})$ studied the Cenozoic succession in several seismic sections from the North Sea, and proposed the first relative sea-level curve for the North Sea. Stewart (1987) recognized ten seismic stratigraphic sequences in the early Palaeogene deposits northwest of our study area. Mudge and Bujak (in press) divided the Eocene in the central and northern North Sea into five stratigraphical sequences bounded by high gamma ray peaks.

\section{Stratigraphic interpretation and correlation}

The traditional stratigraphic interpretation of the Tertiary succession in the North Sea Basin has primarily been based on lithostratigraphy and biostratigraphy. A chronostratigraphic correlation between North Sea well sections and onshore outcrops are generally based on biostratigraphy. 


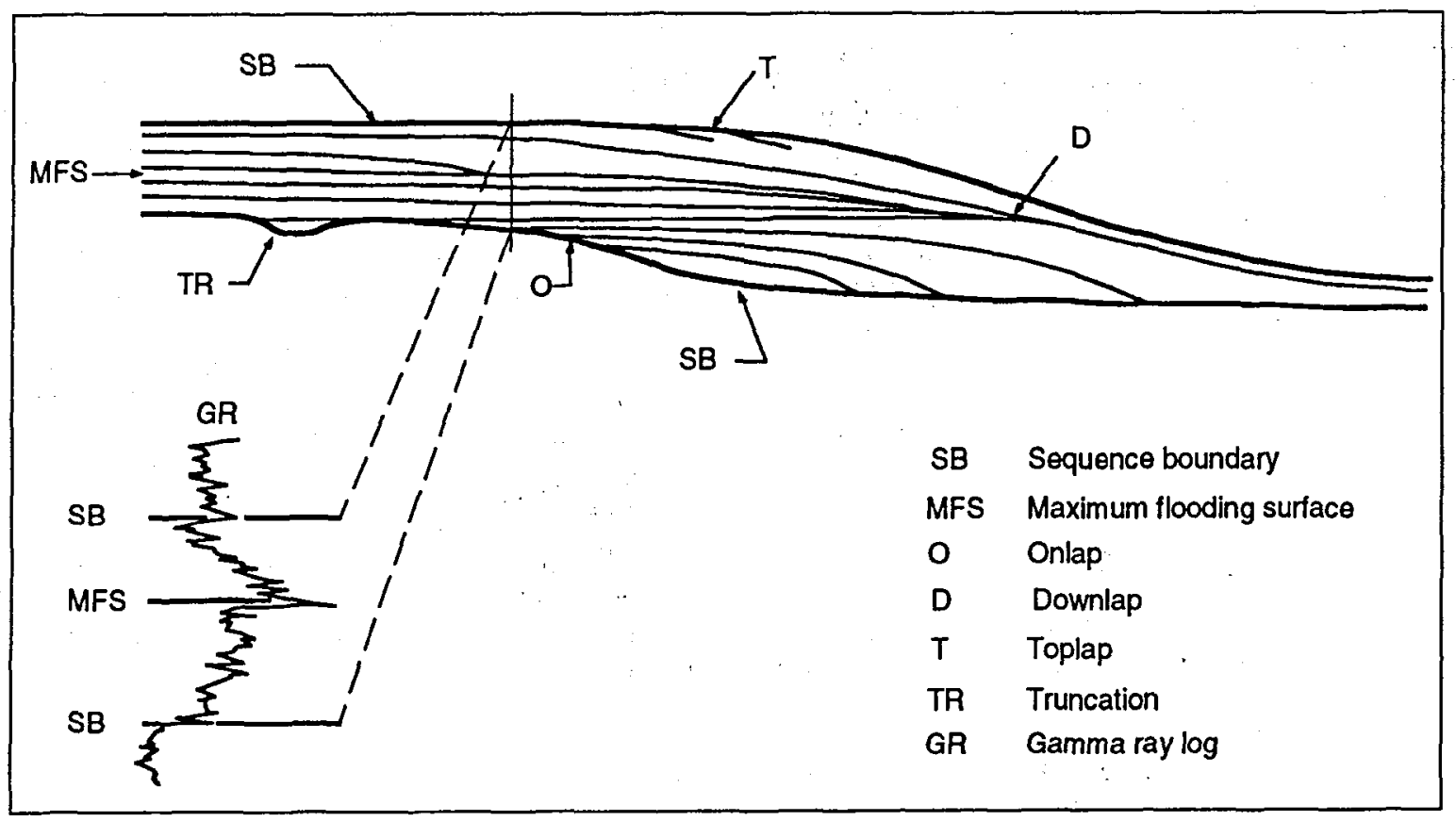

Fig. 3: Principles of identification of sequence boundaries and maximum flooding surfaces. - On seismic sections the sequence boundaries are identified by onlaps and downlaps at the lower boundary and toplaps and truncation features at the upper boundary. The gamma ray log-motif of the sequence consists normally of one cycle with upward increasing values succeeded by upward decreasing values. The two log trends are separated by an interval with the high gamma ray readings, which is identified as the maximum flooding surface.

The accuracy of the chronostratigraphic correlation depends on the fossil groups present in the deposits and on the available samples. There are rather great variations in the time-span of the different biozone, e.g. dinoflagellate zones show a higher stratigraphic resolution than foraminiferal zones, and agglutinated foraminifera are more dependent on facies than calcareous foraminifera. Identification of biozones also depend on the quality of the samples. Outcrop samples from the onshore area can precisely be located within the section, whereas cuttings samples from the North Sea wells represent a 3-10 metres interval, and are often influenced by cavings from the overlying deposits.

Different lithostratigraphic schemes are established in the Danish onshore area and in each of the North Sea sectors (Fig. 2). The Danish onshore section is subdivided into a large number of formations (Buchardt-Larsen \& Heilmann-Clausen, 1988). The post-Danian sediments in the central North Sea is subdivided into two or three groups, and only the Paleocene section is referred to a succession of formations (Isaksen \& Tonstad, 1989, Knox \& Holloway, 1992). The lateral extension into the North Sea of the Danish onshore lithostratigraphic units is often difficult to identify, probably due to differences in the quality between the offshore and onshore samples.

Sequence stratigraphic and allostratigraphic methods may be important for defining a coherent stratigraphic scheme of the North Sea Basin. The character of these two methods will therefore be reviewed below.

\section{Sequence stratigraphy}

The purpose of the North Sea Cenozoic Study was to subdivide the sedimentary succession into genetically related units bounded by surfaces, which have a chronostratigraphic significance. According to the sequence stratigraphic model described by Van Wagoner et al. (1988), a hierarchy of units and surfaces exists.

The smallest unit in the sequence is the parasequence, which is a natural succession of beds showing upward shallowing water depths. The parasequences are separated by flooding surfaces. Parasequences are below seismic resolution, but may be identified on the gamma ray $\log$, according to our experience. A number of parasequences can be grouped into parasequence sets with either a prograding, aggrading, or retrograding trend. These trends are characteristic of different systems tracts. In the siliciclastic deposits of the North Sea Cenozoic succession, the systems tracts may be identified on the gamma ray log as intervals with upward decreasing, constant, or increasing gamma ray values. These log trends are interpreted as corresponding to prograding, aggrading, or retrograding systems, respectively. The systems tracts are difficult to recognize on seismic sections, in 
some cases because they are below seismic resolution and in other cases because their bounding surfaces are difficult to identify on the seismic sections.

A succession of systems tracts constitute one sequence. The sequence is defined as deposited in the period between two sea-level falls (Van Wagoner et al., 1988). The sequence boundary is characterized by an abrupt change in the depositional environment, from relative deep water to shallower water conditions. The corresponding facies change in siliciclastic Cenozoic deposits is often recognizable on the gamma ray $\log$ as a sharp decrease in gamma ray values. Due to the sea-level fall, the sequence top may be characterized by truncations (erosional features) and toplaps (indicating a sediment bypass situation). The base of the overlying sequence is characterized by onlaps, created during the following sea-level rise. A sequence is, therefore, defined as a sedimentary unit bounded by unconformities and their correlative conformities (Van Wagoner et al., 1988).

Another important surface is the maximum flooding surface. This surface represents the most landward shift in facies, and it is located within the most fine-grained part of the sequence, between the upward fining transgressive systems tract and the upward coarsening highstand systems tract. The maximum flooding surface correlates with a condensed section in the basinward direction. The sediments at this surface are often glauconitic or rich in organic matter. Therefore, the maximum flooding surface is recognized rather easily on logs as a gamma ray peak with high values. On the seismic section, it corresponds to a downlap surface at the base of the prograding highstand systems tract.

The sequence stratigraphic interpretation of the Cenozoic in the Danish North Sea sector was hampered for the following reasons: 1) A valid parasequence interpretation was only possible in a few cases. 2) It was only in part possible to identify the bounding surfaces of systems tracts on the seismic sections, and 3) the sediments within the North Sea area are dominated by clay and silt, and generally the facies variations could not be interpreted satisfactorily. Furthermore, the proximal part of the sequences are located outside the study area or have been removed by erosion.

The sequence boundaries were identified mainly in the depocentres by seismic onlap, toplap, and truncation features (Fig. 3). They were correlated to log data and adjusted by means of the gamma ray log or occasionally the sonic log. The gamma ray log-motif of our sequences consists normally of one cycle with upward increasing values succeeded by upward decreasing values, probably representing a succession with upward decreasing grainsize followed by upward increasing grain-size (Fig. 3). The two log trends are separated by a gamma ray maximum. The observations indicate that this narrow interval with the high gamma ray readings, at least in some cases, reflect sediments rich in glauconite or in organic matter. The interval correlates with an internal downlap surface on the seismic sections, and it is synchronous according to the biostratigraphy. The interval were, therefore, identified as a maximum flooding surface (Fig. 3).

To establish chronostratigraphic control of sequence boundaries and maximum flooding surfaces, biostratigraphic analyses have been carried out. The foraminifera were studied in the Upper Eocene to Quaternary section. The dinoflagellate analyses were made primarily in the Palaeogene interval, but also covered the Neogene in one well. The calcareous nannofossil analyses were carried out in the Upper Eocene to Middle Miocene section.

The stratigraphic resolution of the applied biostratigraphy relative to that of the sequence stratigraphy changes through the investigated section. In the Paleocene and Eocene sections, a very detailed biostratigraphic zonation exists, which have lead to a rather precise chronostratigraphic determination. The chronostratigraphic control of the Oligocene sequences is based on an integrated biozonation of all three fossil groups, giving a welldocumented correlation. The resolution of the Miocene sequences is higher than that of the applied foraminifera zones.

\section{Allostratigraphy}

The North American Stratigraphic Code has formalized sedimentary units bounded by unconformities as allostratigraphic units (see Schoch, 1989). The allostratigraphic units are comparable to lithostratigraphic units. The major difference is that allostratigraphic units are identified by the bounding unconformities, whereas the lithostratigraphic units are based on lithological characteristics. The fundamental allostratigraphic unit is the alloformation, and allogroups and allomembers are of higher and lower rank, respectively.

According to the North American Stratigraphic Code, the purpose of allostratigraphy is to distinguish between unconformity-bounded deposits, which may be contiguous or geographically separated. The internal characteristics (lithology and palaeontology) may be similar or vary laterally and vertically throughout the unit. A detailed identification of lithology and variations in lithofacies is fundamental in lithostratigraphy, but is not required for definition of allostratigraphic units. The before-mentioned variations in quality of the samples from different parts of the North Sea Basin is therefore of less importance.

The Code furthermore emphasizes that it is inappropriate to identify genetic relationships for defining the unit. Genetic relationships between the Danish offshore and onshore deposits may be difficult to establish at present. The sequences identified in the North Sea have not been traced into the onshore area, but some of the North Sea sequence boundaries are correlated with onshore regional unconformities on the basis of biostratigraphic data (Michelsen et al., in press/a).

The sequence boundaries and the time-equivalent unconformities constitute regional stratigraphic surfaces, which seem to be suitable for defining allostratigraphic 

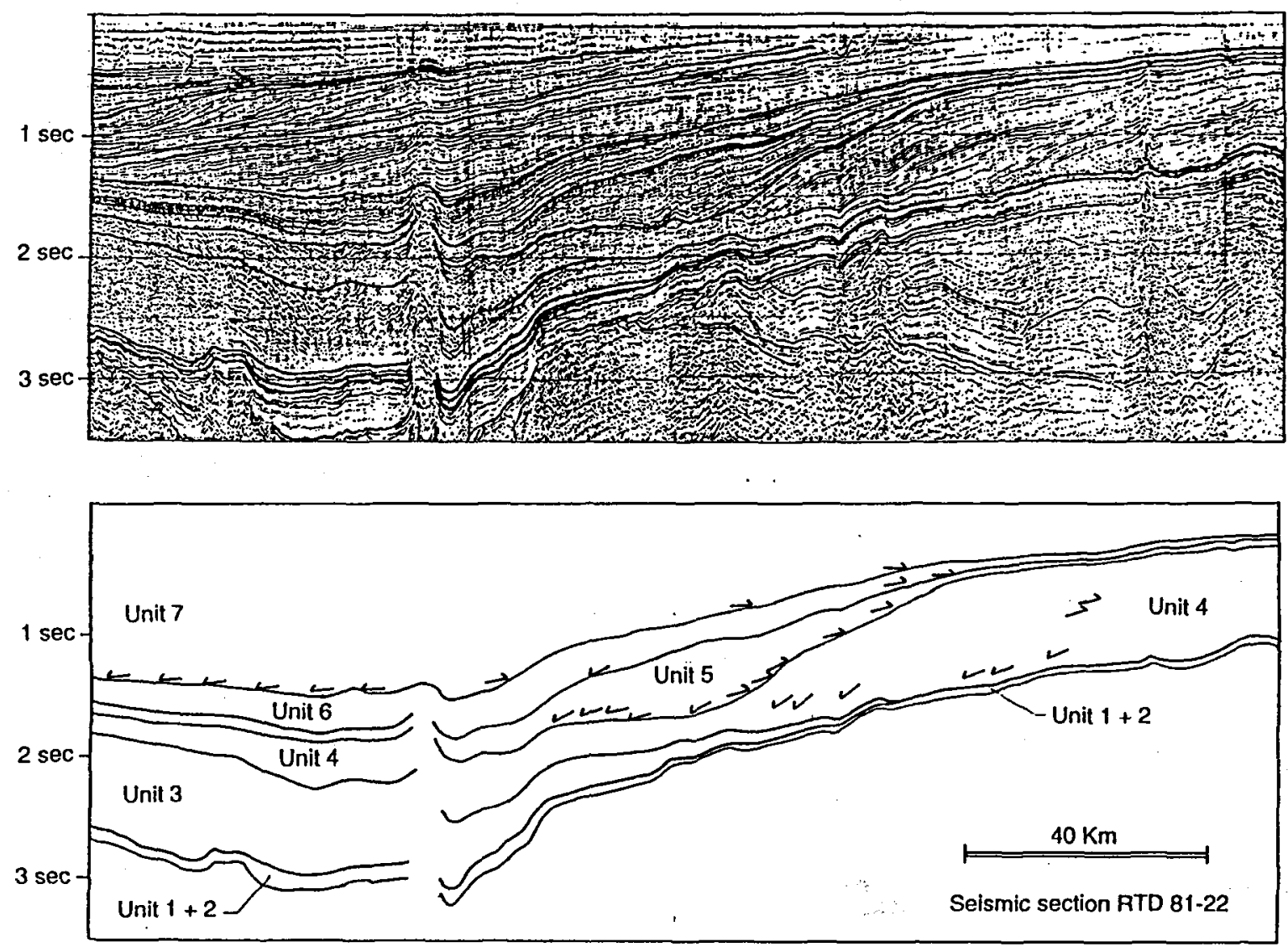

Fig. 4: A geosection based on the seismic section RTD81-22 showing the units 1-2, 3, 4, 5, 6, and 7. The concordant reflections of units 1 and 2 and the overlying chaotic pattern of unit 3 is illustrated. The prograding to aggrading character of units 4,5 , and 6 and the overall aggrading character of unit 7 are seen. Interpretation by Henrik Jordt. For location see Fig. 1.

units with a large lateral extension within the North Sea Basin and with a chronostratigraphic significance.

Identification of regional unconformities based on integrated biostratigraphic, lithostratigraphic, and sequence stratigraphic studies is the basis for the allostratigraphic units, suggested later in this paper.

\section{North Sea sequences}

\section{Sequence stratigraphic framework}

Seven informal major sequence stratigraphic units are identified in the post-Danian Cenozoic of the Danish North Sea sector (Figs 2 and 4).

Unit 1 includes the Upper Paleocene deposits (above the Danian limestone) and the lowermost Eocene deposits, and unit 2 is referred to the Lower Eocene (Fig. 2). The depocentres of the two units are located north of the Danish sector, and shows a southward progradation. Unit
3 is referred to the Middle and Upper Eocene. The depocenter is located at the western border of the Danish Central Trough, and an eastward progradation is indicated. Units 4, 5, and 6 include Oligocene to lower Middle Miocene deposits. The sediment transport was mainly from the north and northeast. The depocentres are located in the Norwegian-Danish Basin and on the Ringkøbing-Fyn High, with unit 4 at the most northeastward position and units 5 and 6 gradually displaced in the westand southwest directions. Unit 7 is of Middle Miocene to Recent age, and represents the latest infilling phase of the Cenozoic North Sea Basin. The depocenter is located centrally in the North Sea, and the prograding part of the unit indicates a sediment transport from the east.

Units 1 and 4-7 can be subdivided into two or more sequences, whereas a clear subdivision of units 2 and 3 not yet is confirmed (Fig. 2). In total, twentyone sequences were identified in the Danish offshore area. The sequences are defined on seismic sections within the respective depocentres, and they are identifiable on logs 
Fig. 5: Gamma ray and sonic log features of the sequences in the Cleo-1, Elna-1, L-1, Ibenholt-1, and . F-1 wells. The base of unit 4 is chosen as the datum line to emphasize the prograding character units 4,5 , and 6 . Note the presence of thick sand bodies in unit 4 in the Inez-1 well Interpretation by Mette Danielsen. For. location see Fig. 1.
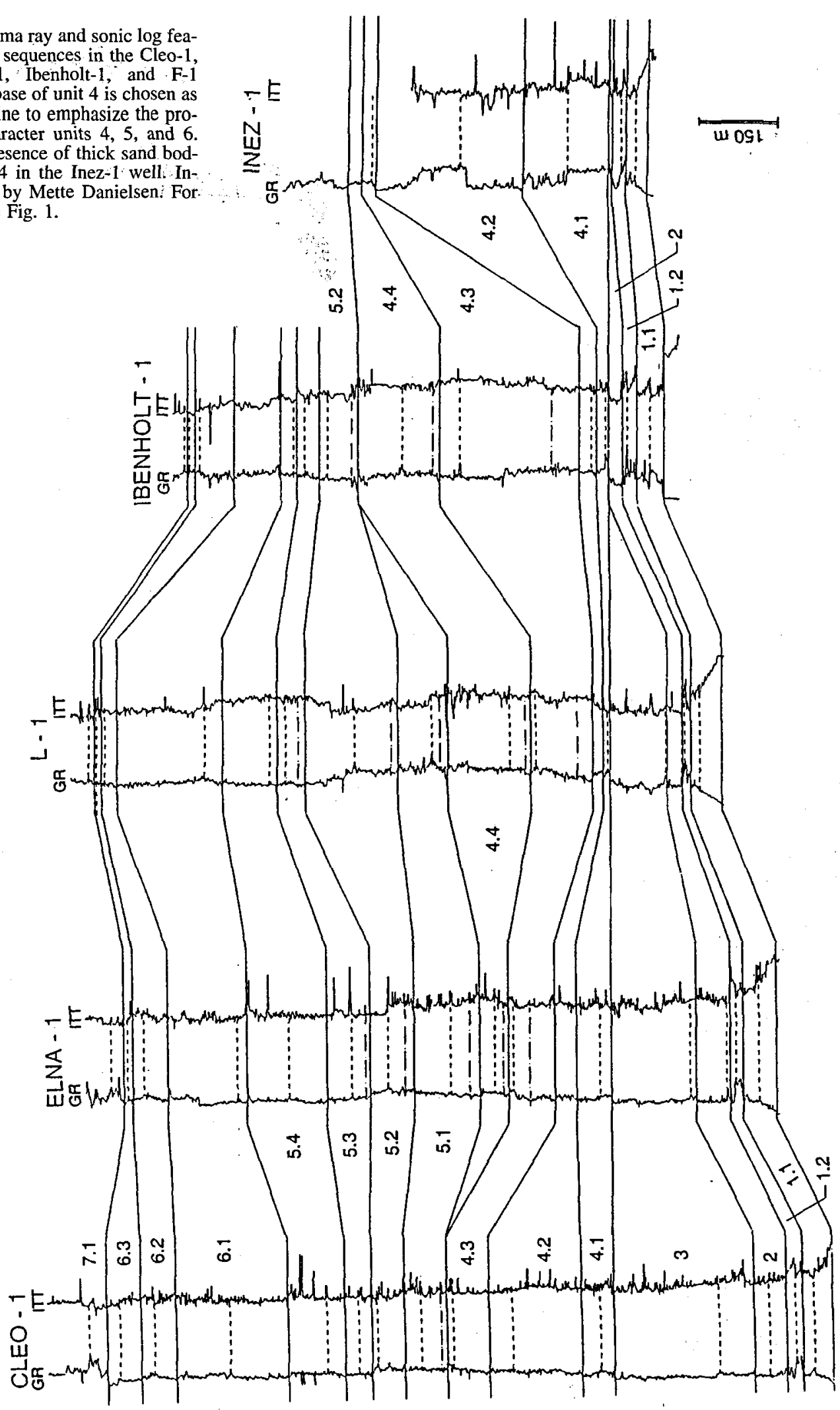


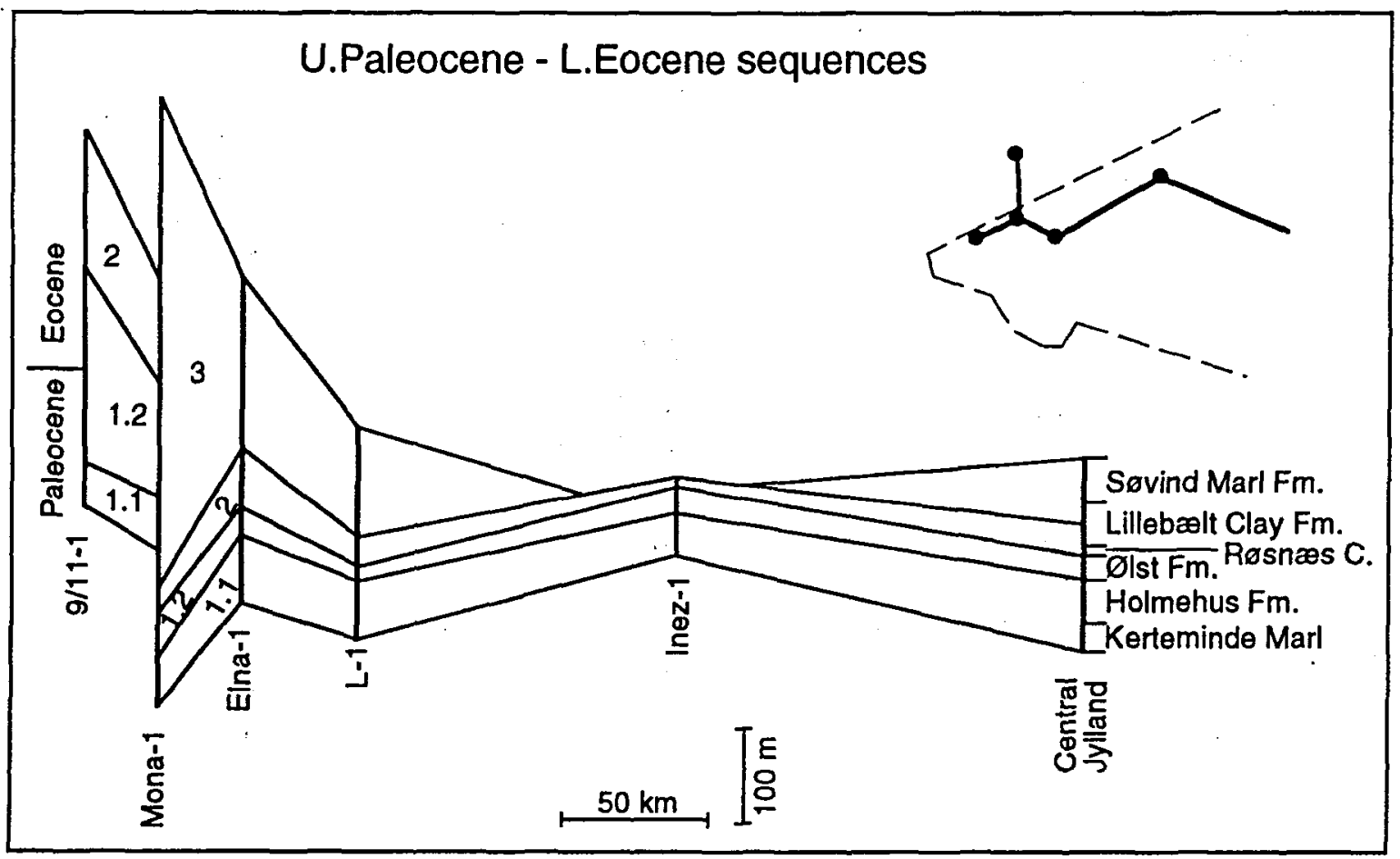

Fig. 6: A fence-diagram showing regional thickness variation of units 1, 2, and 3, including the corresponding sequences. The units and the sequences are correlated with the thicknesses of the formations known from central Jylland, e.g. in the Viborg-1 well. For location see Fig. 1.

in main part of the study area (Fig. 5). In some cases it has been difficult to tie them around in larger areas, probably because they are locally beyond seismic resolution. Within the limits of our biostratigraphy, the sequences are isochronous in the studied wells (Michelsen et al. in press/a).

The boundaries between the major sequence stratigraphic units are easily recognized by means of seismic sections in the entire study area, and they are interpreted to reflect major events in the basin development (Michelsen et al. in press/b). Some of the units seem to correlate with some of the tectonosequences recently published from the central and northern North Sea Basin by Galloway et al. (1993). A correlation between our units and the tectonosequences is difficult to establish on the basis of the available data, and the criteria for identification of the tectonosequence boundaries seems to differ from those described in a previous chapter of this paper. Furthermore, the origin of our major sequence boundaries are not known satisfactorily at present. Further evaluations of the controlling factors (eustatic sea-level changes, tectonic events and changes of sediment supply pattern) are necessary for an evaluation of the relationships between the two sequence stratigraphic interpretations.
Regional variations in thicknesses and lithology

The geometry of the major sequence stratigraphic units has been mapped on the basis of seismic sections, whereas the thickness variation of each sequence is best demonstrated by well sections (Figs 4 and 5). The lithology of the sequences is based on interpretation of logs, supported by information from cuttings sample. The fence-diagrams in Figures 6-8 indicate the regional distribution and thickness variation of the sequences, and include a correlation between the North Sea sequences and the Danish onshore formations. The formation thicknesses indicated in Figures 6 and 7 derive from the Viborg-1 borehole (Heilmann-Clausen et al,, 1985), whereas arbitrary formation thicknesses are used in Figure 8 .

Unit 1 comprises two sequences, 1.1 and 1.2 (Fig. 2). The Danish North Sea sector is located basinward of the unit depocenter and the thickness of unit 1 is here less than 50 $\mathrm{m}$, often $15-20 \mathrm{~m}$ thick (Figs 5 and 6). Unit 1 is not identified in the southern Horn Graben area (S-1 well). The top of the unit is recognized as a strong continuous seismic reflection within a concordant reflection pattern (Fig. 4). The log motif of the unit is rather equal in most of the wells, indicating only minor lateral variations in lithology (Fig. 5). 


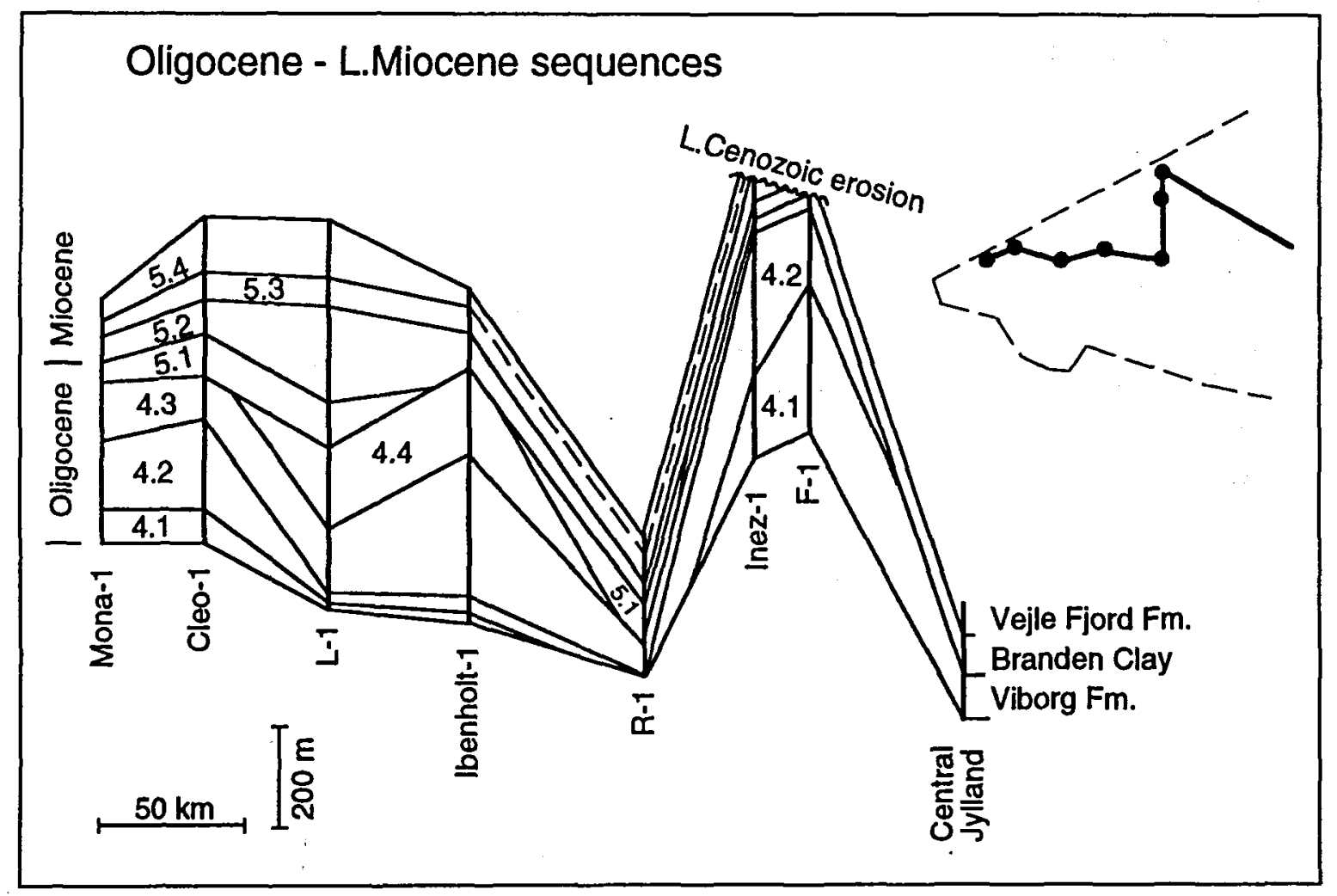

Fig. 7: A fence-diagram showing regional thickness variation of units 4 and 5 , including the corresponding sequences. The units and the sequences are correlated with the thicknesses of the formations known from central Jylland, e.g. in the Viborg-1 well. For location see Fig. 1.

The lower part of sequence 1.1 consists of marl with an upward increasing clay content, corresponding to the North Sea Marl (Fig. 2). The upper part consists of non-calcareous, dark grey silty clay overlain by smectite rich, greenish and reddish clay.

Finely laminated, silty clay with a high content of organic matter occurs lowermost in sequence 1.2, corresponding to the Sele Formation (Fig. 2). The volcanic ash series in the upper part of sequence 1.2 corresponds to that of the Balder Formation (Fig. 2).

Unit 2 is regarded as one sequence, and a further subdivision is not obvious on basis of the present data. The thickness is less than $50 \mathrm{~m}$ in the major part of the area, but exceeds $50 \mathrm{~m}$ in the Central Trough area (Figs 5 and 6). The unit is not observed in the southern Horn Graben area (S-1 well). A continuous seismic reflection marks the top of the unit in the Danish sector (Fig. 4).

Unit 2 consists of fine clay, being reddish in the lower part and greenish in the upper part.

Unit 3 is characterized by a chaotic seismic reflection pattern, which make a further subdivision very difficult (Fig. 4). Log data from some Norwegian wells, however, indicate that unit 3 may include at least two sequences. The thickness varies from $700-800 \mathrm{~m}$ in the western part of the Danish Central Trough area to less than $100 \mathrm{~m}$ on the Ringkøbing-Fyn High and in the Norwegian-Danish Basin (Figs 5 and 6). The unit is thin or absent in the eastern part of the Danish North Sea sector.

Unit 3 represent a period with sediment transport from west. Non-calcareous, very fine-grained, smectite rich, greenish grey clay with an agglutinated foraminiferal fauna dominates the deposits in the western part of the area. The agglutinated foraminiferal fauna and the absence of calcareous nannofossils indicate a relatively deep setting with somewhat aggressive bottom water (cf. King, 1983). In the easternmost part of the area, e.g. in the S-1 well, occurs a thin section of marly sediments, which is equivalent to the youngest part of the Danish onshore Søvind Marl Formation.

Unit 4 comprises the four sequences $4.1,4.2,4.3$, and 4.4 (Fig. 2). The maximum thickness, approx. $900 \mathrm{~m}$, is found in the Norwegian-Danish Basin, at the boundary between the Norwegian and the Danish sectors. In the Central Trough, the thickness decreases to $200-300 \mathrm{~m}$, and on the Ringkøbing-Fyn High to approx. $100 \mathrm{~m}$ (Figs 


\section{L. - M. Miocene sequences}

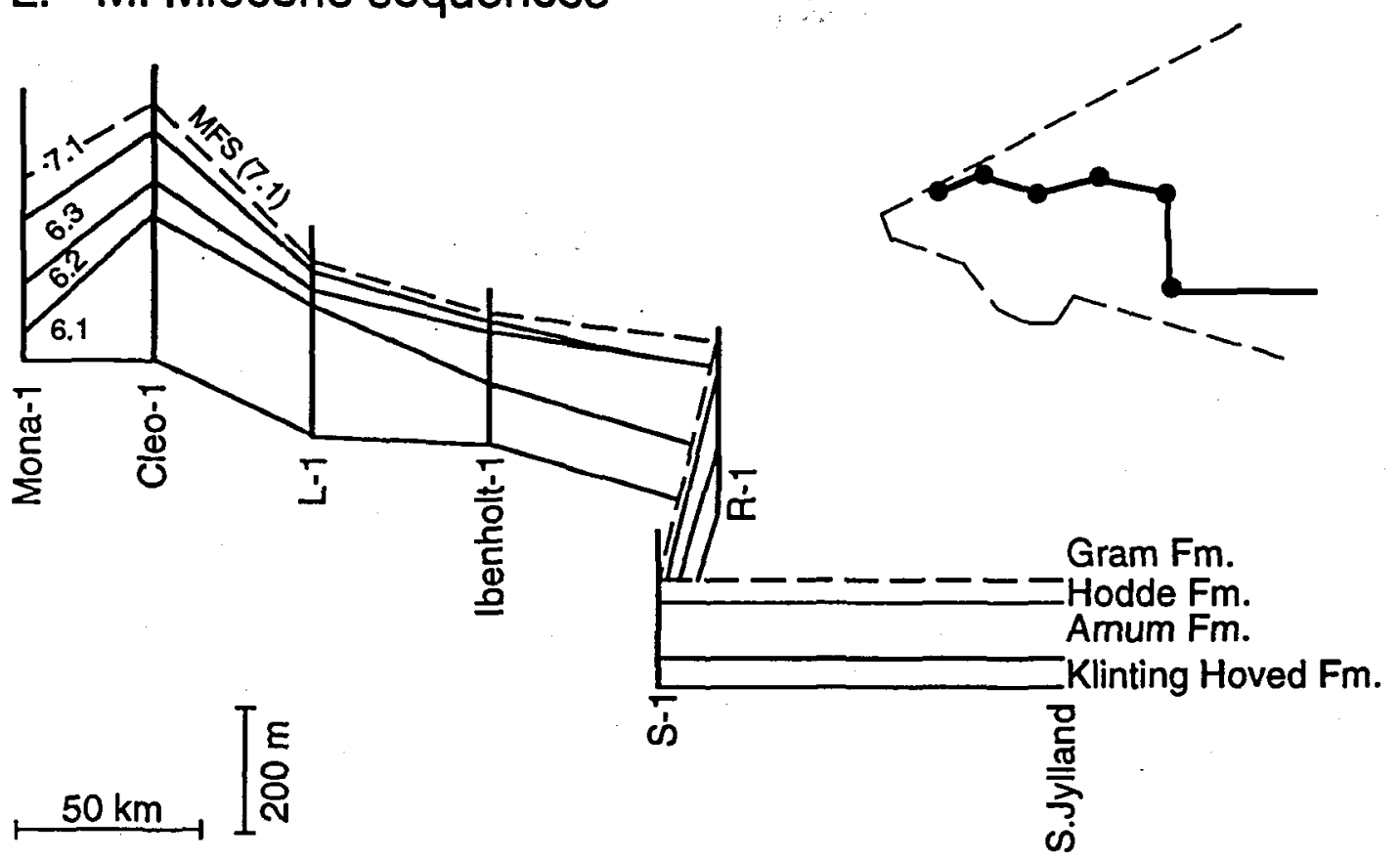

Hodde Fm. Amum Fm.

$\frac{\text { 둘 }}{\bar{\pi}}$

Fig. 8: A fence-diagram showing regional thickness variation of units 6 and 7 (lowermost part), including the corresponding sequences. The units and the sequences are correlated with the formations known from southern Jylland. The relative thicknesses of the formations are not indicated. - MFS (7.1) is the maximum flooding surface represented by the gamma ray peaks lowermost in unit 7. For location see Fig. 1.

5 and 7). Towards the north, the unit is truncated by Quaternary deposits, probably due to the late Cenozoic uplift and erosion (Doré, 1992). Sequences 4.1 and 4.2 thins at the northern flank of the Ringkøbing-Fyn High, $\mathrm{L}-1$ and Ibenholt-1 wells, and they are not recognized in the Horn Graben, R-1 and S-1 wells (Fig. 7). Sequence 4.3 occurs in the entire area, whereas sequence 4.4 is absent or very condensed in the Central Trough area. Unit 4 is characterized by a prograding reflection pattern (Fig. 4), which is a marked contrast to the concordant reflection pattern of the underlying units.

The base of unit 4 (lowermost Oligocene) marks the beginning of a new period with sediment transport from the north and northeast. The deposits show a clear change in lithology from a fine-grained clay-dominated deposit below the boundary to a clay with silt and mica above. The change in lithology and in sediment transport direction was probably controlled by the start of the late Cenozoic uplift.

Olive grey to brownish grey, silty clay dominates the lithology, which is also characterized by a higher content of silt, mica, illite, and kaolinite than in the underlying unit 3. Thick sections of sand occur the northeastern part of the Danish sector (see Inez-1 in Fig. 5). These sand bodies are interpreted as shallow marine sediments, deposited during a westward migration of the shoreline.

Unit 5 is subdivided into the four sequences 5.1, 5.2, 5.3, and 5.4 (Fig. 2). A maximum thickness of approx. $500 \mathrm{~m}$ is found at the northern flank of the Ringkøbing-Fyn High, southwest of unit 4 depocenter. The lower boundary of the unit is characterized a pronounced basinward shift in position of onlaps (Fig. 4), indicating a major fall in relative sea level. Sequence 5.1 occurs in the western and central parts of the Danish sector, but pinches out towards the northeast (Fig. 7), probably due to a low relative sea level. Sequences 5.2, 5.3, and 5.4 are present in the entire area, but to the northeast, they are truncated by Quaternary deposits, probably due to the late Cenozoic uplift and erosion (Doré, 1992).

Silty clay with varying amounts of sand and mica dominates unit 5. The colour changes upward from grey to dark brown or almost black, probably caused by an upward increase in organic matter. The content of silt and sand also increases markedly upward.

Unit 6 is subdivided into the three sequences 6.1, 6.2, and 6.3 (Fig. 2). A maximum thickness of more than $500 \mathrm{~m}$ is 
found at the western border of the Ringkøbing-Fyn High, south of the unit 5 depocenter. Unit 6 is present in most of the area, but it is truncated by Quaternary deposits in the northernmost part of the area, probably due to the late Cenozoic uplift and erosion. Sequence 6.3 has, however, a more restricted distribution (Fig. 8). It pinches out towards the east, and is absent in the Horn Graben (R-1 and $\mathrm{S}-1$ ).

Unit 6 consists of dark greenish grey to dark brown clay, containing an upward increasing amount of organic matter. The content of silt and sand is higher than in the underlying unit 5 , and increases upward.

Unit 7 is preliminarily subdivided into six sequences, of which the upper two sequences are of Quaternary age (Fig. 2). The most recent studies indicate, however, the presence of larger number of sequences. A maximum thickness of $1600 \mathrm{~m}$ is found in the Norwegian Central Trough. The thickness decreases gradually eastwards to less than $300 \mathrm{~m}$. The unit is absent in the northeastern part of the area, probably due to the late Cenozoic uplift and erosion. The large thickness found in the central North Sea indicates an increase in subsidence rates.

The lower boundary of unit 7 is represented by a downlap surface on seismic sections from the Central Trough area (Fig. 4). The downlap surface corresponds to a thin interval with upward increasing gamma ray values ending with one or two high gamma ray peaks (Fig. 5). This interval corresponds to the so-called mid-Miocene unconformity (Deegan \& Scull, 1977). It is often below seismic resolution, but it represents a time interval spanning across two foraminiferal zones. The deposits in this interval consist of black smectite-dominated clay rich in organic matter, and at least one of the gamma ray peaks represents glauconitic sediments. A change to light olive grey sediments, accompanied with a decrease in the content of organic matter and a change to illite- and kaolinite-dominated clays, occurs above this lower interval. The content of silt and sand fluctuates considerably in the upper part of unit 7 , but a general upward increase in coarse-grained material is evident. The decrease in the amount of organic matter reflects a return to well-oxygenated bottom water conditions.

\section{Stratigraphic correlation of the North Sea sequences with the onshore formations}

A correlation of the North Sea sequences and major sequence stratigraphic units with Danish onshore formations and with well-established lithostratigraphic units in the adjacent North Sea sectors is presented in figure 2. The correlation is based on lithology and sequence stratigraphic surfaces, and on the detailed biostratigraphy carried out in fourteen North Sea wells and Danish onshore sections. The description below will emphasize on correlation of major sequence stratigraphic surfaces.

\section{Upper Paleocene and lowermost Eocene}

The lower boundary of unit 1 (base sequence 1.1) corresponds to the contact between the Danian limestone and the overlying North Sea Marl (Fig. 9). Erosional features in the top of the limestone are observed on the Ringkøbing-Fyn High. The boundary corresponds to the boundary onshore Denmark between the Danian limestone and the Kerteminde Marl, between the Chalk Group and the Montrose Group in the British North Sea sector, and between the Vale Formation and the Ekofisk Formation in the Norwegian sector (Fig. 2).

The boundary between sequences 1.1 and 1.2 corresponds to the boundary between the Norwegian Lista and Sele Formations (Fig. 2), and it is time-equivalent with the unconformity at the base the Danish onshore Ølst Formation (Fig. 9). Lithological succession of sequence 1.1 corresponds to that of the Kerteminde Marl, "grey clay", and Holmehus Formation.

The upper boundary of unit 1 (top of sequence 1.2) corresponds to the top of the lowermost Eocene Balder Formation, the volcanic main ash phase. The boundary corresponds to the boundary between the Montrose and Stronsay Groups in the British North Sea sector (Fig. 2). It is time-equivalent with the regional unconformity above the Danish onshore Ølst and Fur Formations (Fig. 9). At most onshore localities, the hemipelagic red clay of the Røsnæs Clay Formation overlies the Ølst Formation. A glauconitic horizon occurs at the base of the red Røsnæs Clay (Heilmann-Clausen et al., 1985).

The lower and the upper.boundaries of unit 1 are easily identified on seismic sections and logs, and they are recognized in the main part of the study area. The boundary between sequences 1.1 and 1.2 is mainly recognized on logs, and locally, it may be more difficult to identify

Fig. 9: The chronostratigraphic scheme comprises a WSW-ENE oriented section from the Central Trough to the F-1 well (Norwegian-Danish Basin) and a N-S oriented section through the Horn Graben from the F-1 well to the S-1 well. A chronostratigraphic correlation between the North Sea sequences and the Danish onshore formations is presented.

Vertical hatching indicates non-depositional or erosional hiati; the dotted signature indicate condensed sections (starved sedimentation) or non-depositional hiati. - A.Fm: Arnum Formation, B.C: Branden Clay, D.L: Danian limestone, G.Fm: Gram Formation, H.Fm: Hodde Formation, Hh.Fm: Holmehus Formation, K.Fm: Klinting Hoved Formation, K.M: Kerteminde Marl, L.C.Fm: Lillebælt Clay Formation, O: Odderup Formation, R: Ribe Formation, R.C.Fm: Røsnæs Clay Formation, S.Fm: Sæd Formation, S.M.Fm: Søvind Marl Formation, V.F.Fm: Vejle Fjord Formation, V.Fm: Viborg Formation, Ø.Fm: Ølst Formation. 


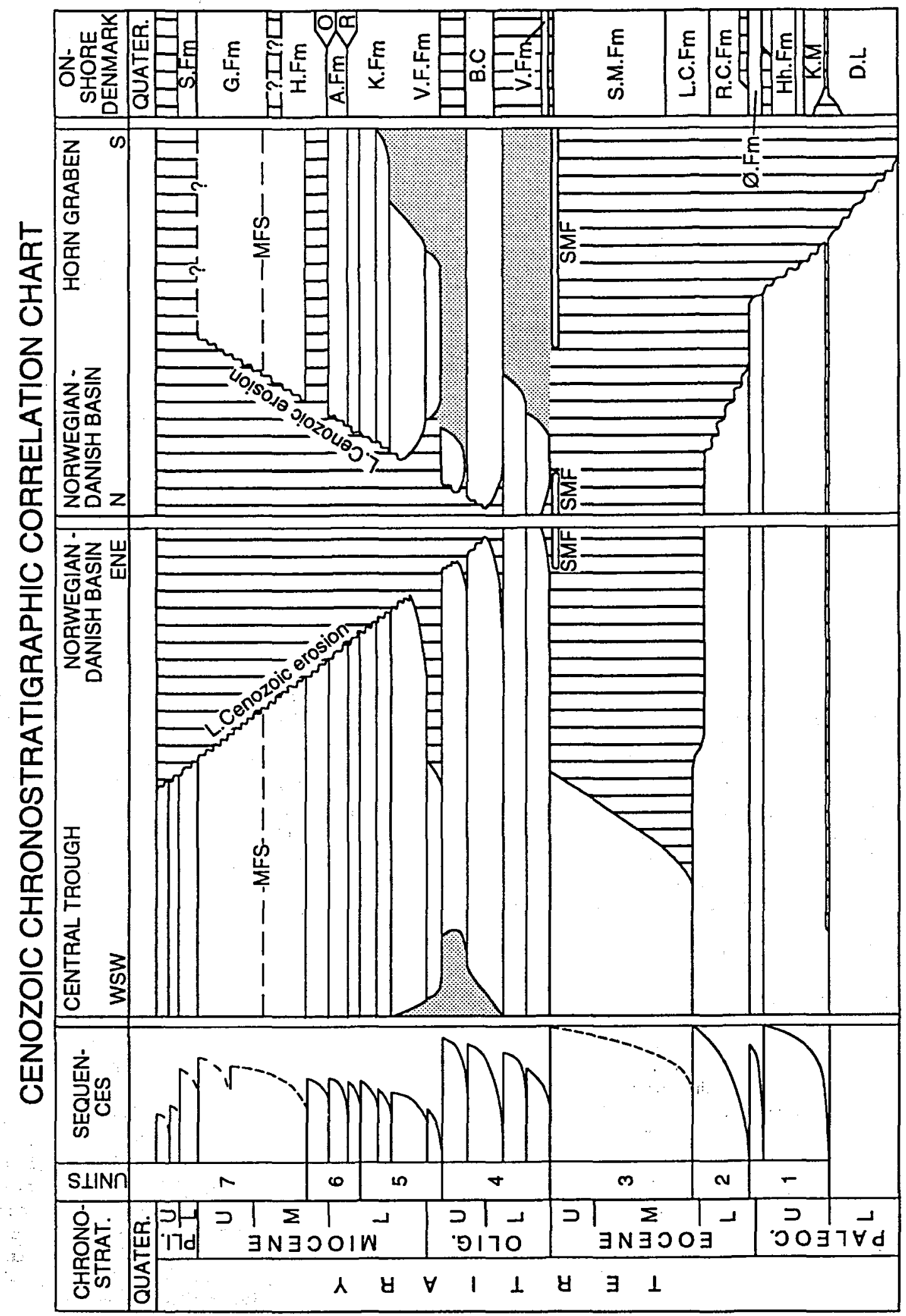


on seismic data, probably due to the small thickness of unit 1.

\section{Eocene}

The lithology of unit 2 corresponds to that of the Danish Røsnæs Clay and Lillebælt Clay Formations. The boundary between units 2 and 3 can not be correlated with a regional hiatus in the Danish onshore deposits, but the biostratigraphy indicates that a time-equivalent boundary is positioned within the Lillebælt Clay Formation (Figs 2 and 9). The boundary separates in the central North Sea deposits with a dominant sediment transport from north below the boundary (unit 2) from sediments with a transport from west above the boundary (unit 3 ). The indicated change in sediment source across the boundary is possibly reflected in the Danish Lillebælt Clay Formation at the transition from $\mathrm{L} 4$ to $\mathrm{L} 5$, where an abrupt change to a smectite-dominated deposit is recognized (HeilmannClausen et al., 1985). The Lillebælt Clay Formation seems thus to correlate with the upper part of unit 2 and the lower part of unit 3 (Fig. 9). The sequence stratigraphic features observed at the depocenter, north of the Danish North Sea sector, indicate the presence of an unconformity at the boundary between units 2 and 3 . In the sediments deposited more distally, as within the Danish sector, an unconformity is neither observed on the seismic sections nor in the biostratigraphic data.

Unit 3 is time-equivalent with upper part of the Lillebælt Clay Formation and the Søvind Marl Formation (Fig. 2). It is an extremely thick and a relatively deep water deposit compared with the rather thin and more shallow water deposits onshore Denmark (Fig. 6). There is probably no physical contact between the two sedimentary bodies within the Danish North Sea sector (Fig. 9). The non-calcareous, fine-grained clay deposits in the central North Sea progrades eastward, downlapping in the western Ringkøbing-Fyn High. The marly sediments observed in the easternmost part of the North Sea (e.g. $S-1$ well) are time-equivalent with the uppermost part of the Søvind Marl. A contact between the two sedimentary bodies may occur south of the Danish sector. Seismic sections from the German and Dutch North Sea sectors show the presence of a more than $200 \mathrm{~m}$ thick unit 3. A calcareous facies is observed uppermost in unit 3 in Dutch wells. The palaeogeographical relationships of these two different lithologies and depositional environments are difficult to establish at present.

The suggested hiatus between units 2 and 3 in the eastern North Sea can not be traced in the Danish onshore deposits (Fig. 9). Corresponding difficulties seems to be present in the adjacent part of the British North Sea sector (Knox \& Holloway 1992). The deposits time-equivalent with units 2 and 3 are here referred to one formation, the Horda Formation (Fig. 2).

\section{Oligocene}

The overall lithology of unit 4 corresponds to that known from the Danish onshore Viborg Formation and Branden Clay (Figs 2 and 9). The lower boundary of unit 4 is time-equivalent with the regional unconformity at the base of the Viborg Formation. The slightly upward coarsening trend of the Viborg Formation correlates with lower part of sequence 4.1 (lowermost in unit 4), and the formation represents possibly a lowstand unit. The Branden Clay is isochronous with sequence 4.3. The glauconitic basal part of the Branden Clay, which is characterized by an acme of planktonic foraminifera (Ulleberg, 1987), may correlate with the transgressive part of sequence 4.3 , including the maximum flooding surface.

The remaining parts of unit 4, sequences 4.2 and 4.4, are time-equivalent with the onshore hiati below and above the Branden Clay, respectively (Fig. 9). The North Sea sequence stratigraphic features indicate a significant relative sea-level fall between sequences 4.2 and 4.3 , and a major fall between 4.4 and 5.1. The two hiati are possibly created by these two larger sea-level falls and the subsequent erosion.

The major unconformities at the base and top of unit 4 are mapped in the entire southeastern North Sea and identified in the Danish onshore area.

\section{Uppermost Oligocene to lowermost Middle Miocene}

It is suggested that the base of unit 5 correlates with the base of the onshore Vejle Fjord Formation. The pronounced basinward shift of onlaps at the boundary between units 4 and 5 is probably caused by a major relative sea-level fall (Fig. 4), which may explain the transition from the open marine deposits in the Branden Clay to the shallow water deposits of the Vejle Fjord Formation.

The biostratigraphic correlation of the North Sea units 5 and 6 with the onshore Vejle Fjord, Klinting Hoved, Arnum, and Hodde Formations is not yet established in details. The boundary between units 5 and 6 is positioned within the upper part of the Klinting Hoved Formation, and the upper boundary of unit 6 within the Hodde Formation (Fig. 9).

\section{Uppermost Middle Miocene and Pliocene}

The basal part of unit 7 seems to be isochronous with the upper part of the Hodde Formation and the lowermost part of the Gram Formation (Figs 2 and 9). The thin interval lowermost in unit 7, including the before-mentioned gamma ray peaks (Fig. 5), represents a period with starved sedimentation in the central North Sea. This interval consists of black clay with a high content of organic matter and glauconitic beds occur uppermost in the interval. The interval correlates, according to the biostratigraphy, with the upper dark-coloured part of the Hodde Formation and the lowermost glauconitic part of the Gram Formation, indicating that genetic relationships 
exist between these offshore and onshore deposits. The glauconitic zone of the Gram Formation may thus represent the lowermost maximum flooding surface known from unit 7, and the upper part of the Hodde Formation may represent the associated transgressive trend. The lower boundary of unit 7 may, therefore, be present within the Hodde Formation.

The overlying parts of unit 7 can partly be correlated with the onshore formations. The large number of sequences, indicated by recent studies of unit 7 , are not yet recognized in the onshore sections. A precise chronostratigraphic calibration of these sequences will probably suffer from the fact that the foraminiferal zonation has a lower stratigraphic resolution than the sequence stratigraphy in this part of the Tertiary succession.

Unit 7 correlates with the Nordland Group in the Norwegian and British North Sea sectors. The seismic downlap surface and the corresponding log motifs, including the gamma ray peaks, seem to be identifiable in large parts of the North Sea.

\section{Conclusion}

A precise chronostratigraphic correlation between the North Sea sequences and the Danish onshore formations is described above. The overall correlation is supported by biostratigraphy, which is very detailed in the Palaeogene section. The sequence stratigraphic study has demonstrated that a precise correlation at present is possible at a number of distinct stratigraphic levels.

At least five sequence stratigraphic surfaces occur within the Tertiary in the Danish North Sea sector: base of unit 1, 2, 4, 5, and 7 (Fig. 2). The first four of these surfaces are time-equivalent with regional unconformities onshore Denmark.

The base of unit 7 is not yet correlated with a distinct stratigraphic level in the onshore section, but genetic relationships between the overlying maximum flooding surface and base of the Gram Formation is well-established.

These five surfaces are recognized as major sequence stratigraphic boundaries in the southeastern North Sea. They are interpreted to reflect important events in the Tertiary basin development. Tectonic events may have influenced the transitions between units 3 and 4 and units 6 and 7. The causal relations at the other boundaries are not yet clearly understood, but eustatic sea-level changes may have been important. The boundaries are associated with regional unconformities, and are by definition chronostratigraphic surfaces. A sixth surface is assumed to exist above sequence 7.4 of unit 7, e.i at the base of the Quaternary (Fig. 2). The poor quality in the uppermost part of the seismic section makes an interpretation very difficult.

The six surfaces define five sedimentary units, bounded by unconformities in the southeastern North Sea and onshore Denmark. All five units (A-E) could, there- fore, be defined as allostratigraphic units as proposed in figure 2 . The five units are easily identified by means of seismic sections and $\log$ data in the Danish. North Sea sector, and the adjacent parts of the Norwegian, German, and Dutch sectors. In the Danish onshore area, they are recognized by lithological evidences in outcrops and shallow boreholes.

It is, therefore, suggested that five allostratigraphic units could be described in a coming work on the basis of seismic sections, log data, and lithological features. Since they are based on sequence stratigraphic criteria, each unit belongs to the same chronostratigraphic interval in its total lateral extension.

At present there is established-different lithostratigraphic schemes in the Danish onshore area and in each of the North Sea sectors. A precise lateral extension of the lithostratigraphic units is difficult to identify. The detailed lithology known from Danish outcrops can generally not be recognized in the North Sea samples, except for the Upper Paleocene and Lower Eocene interval. A lateral facies variation may be visible in the younger part of the Tertiary section, but it can not be described satisfactorily for a detailed lithostratigraphic: subdivision. It may, therefore, be difficult to establish a coherent lithostratigraphic scheme, which crosses national borders and the present coastlines.

Definition of the suggested allostratigraphic scheme would be useful for geologists working with the Tertiary in the North Sea region. It would be possible to incorporate the before-mentioned sequences and most of the established lithostratigraphic formations into a chronostratigraphic framework and to indicate the genetic relationships. The allostratigraphic scheme would create a common nomenclature across the national borders and the present coastlines, and hopefully avoid the unprecise and often misleading use of chronostratigraphic terms based on data of varying quality from different profiles.

\section{Acknowledgements}

I greatly appreciate the discussions with Mette Danielsen, Claus Heilmann-Clausen, Henrik Jordt, Gitte V. Laursen, and Erik Thomsen during the sequence stratigraphic interpretation of the North Sea data. Ole Bjørslev Nielsen is thanked for a careful review of the manuscript.

\section{Dansk sammendrag}

Den tertiære lagserie i den sydøstlige del af Nordsøen er op til $3000 \mathrm{~m}$ tyk. Landområdets tertiære lagserie er 6-700 $\mathrm{m}$ tyk, og den omfatter mange regionale inkonformiteter, der adskiller distinkte lithologier (Fig. 2).

På basis af en integreret tolkning af seismik, borehulslogs og biostratigrafi er Nordsøens tertiære lagserie inddelt i 21 sekvenser, fordelt på syv uformelle overordnede sekvensstratigrafiske enheder (Fig. 2). Det se- 
kvensstratigrafiske arbejde er gennemført ved Geologisk Institut (Aarhus Universitet) af Mette Danielsen, Henrik Jordt, Claus Heilmann-Clausen, Gitte V. Laursen, Olaf Michelsen og Erik Thomsen (Michelsen et al. in press/a).

De syv enheders stratigrafiske relation til danske, norske og engelske lithostratigrafiske enheder er beskrevet kortfattet nedenfor (se også Fig. 2).

Enhed 1 omfatter aflejringer fra Øvre Paleocæn (over Danien kalken) og det nederste Eocæn. Enhedens øvre grænse svarer til top af Balder Formationen, og den er tidsækvivalent med inkonformiteten mellem de danske Ølst og Røsnæs Ler Formationer. Enheden består af to sekvenser, 1.1 og 1.2, og grænsen mellem disse korrelerer med grænsen mellem de norske Lista og Sele Formationer. På dansk landområde svarer denne sekvensgrænse til grænsen mellem Holmehus og Ølst Formationerne.

Enhed 2 omfatter aflejringer fra Nedre Eocæn og korrelerer med Røsnæs Ler Formationen og nedre del af Lillebælt Ler Formationen.

Enhed 3 er henført til Mellem - $\emptyset$ vre Eocæn. Enheden korrelerer med den øvre del af Lillebælt Ler og Søvind Mergel Formationerne. Grænsen mellem enhederne $2 \mathrm{og}$ 3 svarer således ikke til en regional hiatus i Danmark, men den kan korreleres med et niveau nær overgangen fra L4 til L5.

Enhederne 4, 5 og 6 henføres til Oligocæn - nedre Mellem Miocæn. Overgangen fra enhed 3 til 4 er markeret ved en ændring i sedimenttransport og en ændring i lithologi fra fint ler i enhed 3 til silt- og glimmerholdigt ler i enhed 4. Sandaflejringer forekommer $\mathrm{i}$ den nordøstlige del af området.

Enhed 4 er en prograderende enhed, der kan henføres til Oligocæn. Den er opdelt i fire sekvenser (4.1-4.4). Nederste del af sekvens 4.1 kan korreleres med Viborg Formationen, medens Branden Leret korrelerer med dele af sekvens 4.3. Basis af enhed 4 kan korreleres med den regionale inkonformitet mellem Viborg Formationen og den underliggende Søvind Mergel Formation.

Grænsen mellem enhederne 4 og 5 udviser sekvensstratigrafiske karakterer, der må tolkes som forårsaget af et markant fald $i$ havniveau. Denne grænse svarer til den omfattende hiatus mellem det fuldt marine Branden Ler og Vejle Fjord Formationens kystnære og lagunale aflejringer.

Enhed 7 er af Mellem Miocæn - Recent alder. Denne enhed repræsenterer den sidste indfyldningsfase $i$ det kænozoiske Nordsø Bassin.

Basis af enhed 7 er karakteriseret ved et tyndt interval med opad stigende gamma ray værdier, som øverst afsluttes med en eller to meget tydelige gamma ray toppe. Den nederste del af intervallet synes tidsakvivalent med $\emptyset$ vre del af Hodde Formationen, og gamma ray toppene med den glaukonitførende zone nederst i Gram Formationen.

Grænserne mellem de syv overordnede enheder er nemme at identificere på de forhåndenværende data (logs og seismik), de har en stor regional udbredelse, og de fleste af dem er tidsækvivalente med regionale inkonfor- miteter kendt fra dansk landområde (Fig. 2). Disse grænser omfatter inkonformiteter, der afgrænser lagserier, som $\mathrm{i}$ hele deres laterale udstrækning er genetisk sammenhørende og som tilhører samme geologiske tidsinterval. På grundlag af de sekvensstratigrafiske analyser synes det således muligt at etablere et stratigrafisk skema, som omfatter dansk landområde og væsentlige dele af Nords $\varnothing$-området.

Der kan etableres en allostratigrafisk inddeling med fem enheder (A-E i Fig. 2), der er afgrænset af regionale inkonformiteter. De fem enheder kan identificeres i det sydøstlige Nords $\varnothing$-område, inklusiv dansk landområde. Enhederne har en stor regional udbredelse, og de strækker sig på tværs af de nationale grænser og af den nuværende kystlinie.

\section{References}

Buchardt-Larsen, B. \& Heilmann-Clausen, C. 1988: The Danish subbasin, Southern Jutland. In Vinken, R. (compiler) The Northwest European Tertiary basin. Geologisches Jahrbuch A $100,83-90$.

Clausen, O. R. 1991: Tertiary Seismic Stratigraphic and Structural Evolution of the northern Danish Central Trough. Unpublished Ph.D. thesis at Aarhus University, $320 \mathrm{pp}$.

Christensen, L. \& Ulleberg, K. 1973: Sedimentology and micropalaeontology of the Middle Oligocene Viborg Formation. Denmark. Bulletin of the Geological Society of Denmark 22, 283-305.

Christensen, L. \& Ulleberg, K. 1974: Sediments and foraminifera of the Middle Oligocene Viborg Formation, Denmark. Bulletin of the Geological Society of Denmark 23, 109-117.

Deegan, C. E. \& Scull, B. J. (compilers) 1977: A standard lithostratigraphic nomenclature for the Central and Northern North Sea. Reports of the Institute of Geological Sciences UK, 77/25, $36 \mathrm{pp}$.

Dinesen, A., Michelsen, O. \& Lieberkind, K. 1978: A survey of the Paleocene and Eocene deposits of Jylland and Fyn. Danmarks Geologiske Undersøgelse B 1, 15 pp.

Doré, A. G. 1992: The base Tertiary surface of southern Norway and the northern North Sea. Norsk Geologisk Tidsskrift 72, $259-265$.

Friis, H. 1978: Heavy-mineral variability in Miocene marine sediments in Denmark: a combined effect of weathering and reworking. Sedimentary Geology 21, 169-188.

Galloway, W. E., Garber, J. L., Xijin Liu \& Sloan, B. J.,1993: Sequence stratigraphic and depositional framework of the Cenozoic fill, Central and Northern North Sea Basin. In J. R. Parker (ed.) Petroleum Geology of Northwest Europe: Proceedings of the 4th Conference, 33-43. The Geological Society, London.

Heilmann-Clausen, C. 1989: Paleogene aflejringer over Danske kalken, In Nielsen, O. B. \& Sandersen P. (eds) Danmarks Geologi - fra $\emptyset$ vre kridt til i dag. Geologisk Institut, Aarhus University 1, $44 \mathrm{pp}$.

Heilmann-Clausen, C., Nielsen, O. B., \& Gersner, F. 1985 Lithostratigraphy and depositional environments in the Upper Paleocene and Eocene of Denmark. Bulletin of the Geological Society of Denmark 33, 287-323.

Isaksen, D. \& Tonstad, K. (eds) 1989: A revised Cretaceous and Tertiary lithostratigraphic nomenclature for the Norwegian North Sea. NPD-Bulletin 5, $59 \mathrm{pp}$.

King, C. 1983: Cainozoic micropalaeontological biostratigraphy of the North Sea. Reports of the Institute of Geological Sciences UK 82 (7), 40 pp.

Knox, R. W. O'B. \& Holloway, S. 1992: 1. Paleogene of the Central and Northern North Sea. In Knox, R.W.O'B. \& Cor- 
dey, W.G. (eds) Lithostratigraphic nomenclature of the UK North Sea. British Geological Survey, 136 pp. Nottingham.

Koch, B. E. 1989: Geology of the Søby-Fasterholt area. Danmarks Geologiske Unders $\varnothing$ gelse A 22, 171 and $121 \mathrm{pp.}$

Kristoffersen, F. N. \& Bang, I. 1982: Cenozoic excl. Danian limestone. In Michelsen, $O$. (ed.) Geology of the Danish Central Graben. Danmarks Geologiske Undersøgelse B 8, 61-70.

Larsen, G. \& Dinesen, A. 1959: Vejle Fjord Formationen ved Brejning. Danmarks Geologiske Undersøgelse II Række, 82, 114 pp.

Michelsen, O., Danielsen, M., Heilmann-Clausen, C., Jordt, H., Laursen, G V. \& Thomsen, E. (in press/a). Cenozoic sequence stratigraphy in the eastern North Sea. In de Graciansky, P.Ch., Jacquin, T. \& Vail, P. R. (eds) Mesozoic-Cenozoic Sequence Stratigraphy of Western European Basins, 2. Society of Economic Paleontologists and Mineralogists (SEPM).

Michelsen, O., Danielsen, M., Heilmann-Clausen, C., Jordt, H., Laursen, G. V. \& Thomsen, E. (in press/b): Cenozoic sequence stratigraphic surfaces in the eastern North Sea. NPF Special Publication.

Mudge, D. C. \& Bujak, J. P. (in press) Eocene stratigraphy of the North Sea Basin: Journal of Sedimentary and Petroleum Geology.

Nielsen, O. B., Sørensen, S., Thiede, J. \& Skarbø, O. 1986. Cenozoic Differential Subsidence of North Sea. The American Association of Petroleum Geologists Bulletin 70 (3), 276-298.

Radwanski, A., Friis, H. \& Larsen, G. 1975: The Miocene Hagenør-Børup sequence at Lillebælt (Denmark): its biogenic structures and depositional environment. Bulletin of the Geological Society of Denmark 24, 229-260.

Rasmussen, L. B. 1961: De miocæane formationer i Danmark. Danmarks Geologiske Undersøgelse IV Række, 4 (5), 45 pp. Rasmussen, L. B. 1974: Some geological results from the first five Danish exploration wells in the North Sea. Danmarks Geologiske Undersøgelse III Række, 42, $46 \mathrm{pp}$.

Rasmussen, L. B. 1978: Geological aspects of the Danish North Sea sector. Danmarks Geologiske Undersøgelse III Række, 44, 85 pp.

Schoch, R. M. 1989: Stratigraphy; Principles and Methods. 375 pp. New York: Van Nostrand Reinhold.

Sorgenfrei, T. 1969: Geological perspectives in the North Sea area. Bulletin of the Geological Society of Denmark 19, 160-196.

Stewart, I. J. 1987: A revised stratigraphic interpretation of the Early Palaeogene of the central North Sea. In Brooks, J. and Glennie, K. (eds) Petroleum Geology of the North West Europe: Graham and Trotman, London, 557-576.

Ulleberg, K., 1987. Foraminiferal zonation of the Danish Oligocene sediments. Bulletin of the Geological Society of Denmark 36, 191-202.

Vinken, R, 1988: The Northwest European Tertiary basin. Geologisches Jahrbuch A 100, $508 \mathrm{pp}$.

Vail, P. R., Mitchum, R. M. \& Thompson, S. 1977a: Relative changes of sea level from coastal onlap. In Payton, C. E. (ed.) Seismic stratigraphy - applications to hydrocarbon exploration. American Association of Petroleum Geologists 26, $63-82$.

Vail, P. R., Mitchum, R. M. \& Thompson, S. 1977b: Global cycles of relative changes of sea level. In Payton, C. E. (ed.) Seismic stratigraphy - applications to hydrocarbon exploration. American Association of Petroleum Geologists 26, 83-98.

Van Wagoner, J. C., Posamentier, H. W.,Mitchum,R. M., Vail, P. R., Sarg, J. F., Loutit, T. S. \& Hardenbol, J. 1988: An overview of the fundamentals of sequence stratigraphy and key definitions. In Wilgus, C. K., Posamentier, H., Roos C. A. \& Kendall, C. G. St. C. (eds) Sea-Level Changes: An Integrated Approach. Society of Economic Paleontologists and Mineralogists, Special Publication 42, 39-45. 